\title{
Code-Switching on Advertisement: \\ A Case of Food Advertisements in Indonesia
}

\author{
Eugenie Mainake \\ Southern Illinois University Carbondale \\ Email: Eugenie.mainake@siu.edu
}

\begin{abstract}
Code-switching is a natural linguistic phenomenon for individuals who understand and use two or more languages interchangeably. Grosjean (2010) argues that code-switching will likely occur to bilingual speakers' speech. Hoffman (1991) confirms that a code-switching is a form of speech creativity of bilinguals. Recently, studies have shown that code-switching is also found on TV commercials in some multilingual countries. In Indonesia alone, Da Silva (2014) has investigated the frequency of English words in Indonesian TV advertisements and Sintya's (2017) study also disseminated products whose advertisements were Indonesian-English code-switching. The present study further explored particular ads, food products for code-switching, and the types of code-switching used. The findings revealed Indonesian-English switches and demonstrated intrasentential switching as the dominantly used switch in the advertisements. The study proposed to investigate the public perspective on such code-switching and the impacts towards the public interest of purchasing the products. Lastly, the author finds it important to view the efficacy of code-switching in TV ads for EFL learners' vocabulary acquisition and retainment.
\end{abstract}

Keywords: bilingualism, code-switching, food advertisement

\section{Introduction}

Code-switching is commonly a natural linguistic phenomenon in bilingual or even multilingual society. Code-switching is typically a characteristic of bilinguals who alternate words, simple phrases, and even sentences from one language to another (Attariba \& Morier, 2006; Da Silva, 2014; Edwards, 2006; Grosjean, 2010). In that sense, one language is inserted into the other language which is primarily used in spoken discourse (Grosjean, 2010).

Code-switching is the normal occurrence of alternation of two or more languages between bilingual speakers' communicative exchange. The switching includes lexical items, clauses, and even phrases. Code-switching is classified into intra-sentential switching, inter-sentential switching, and tag switching (Hoffman, 1991; Romaine, 2000). Code-switching is likely to be performed by 
bilinguals as they have the skills to utilize two or more languages in their interactions. Indonesia, in fact, is a country with a large number of bilingual and multilingual speakers. Sumarsih et al (2014) reported that Indonesians switched from one language to two and three languages. Interestingly, their study found Indonesian-English code-switching and vernacular language-English-Indonesian switching. Such evidence then informed the linguistic situation in Indonesia that invites studies to expand. Additionally, Windyawati and Aurima (2018) confirmed that code-switching plays an essential role in communication and influences the way people interact with languages in Indonesia as they found code-switching on Facebook posts.

Advertisements, as another important media, are a medium to promote products and marketing services to people. Da Silva (2014) added that advertisements provide abundant samples on English code-switching related business field. Moreover, Sintya (2017) identified product ads that involves Indonesian-English code-switching. These studies viewed the impacts of codeswitching use on customers' understanding of language and interest to buy the products. Yet, little work has been done to examine the types of code-switching employed in Indonesian commercials particularly the food products as the increasing demands of the products by the society and numbers of international and local brands established in Indonesia. Therefore, the present study addressed the following research questions to find out.

1. Is there Indonesian - English code-switching on TV Food Advertisements in Indonesia?

2. What types of code-switching are found on TV Food Advertisements in Indonesia?

\section{Literature Review}

\section{Bilingualism}

Bilingualism is defined as conversing with two or more languages alternately. Linguists assert that bilingual speakers have a great mastery of two languages. Those speakers have the ability to speak their native language, termed as mother tongue, and another additional language that functions as a second language. Thus, when two individuals interact with each other uttering two languages interchangeably, they are bilingual, and that they demonstrate bilingualism.

Titone (1993) defined bilingualism as one's ability to speak a second or third language using structures and concepts differed from the mother tongue. Bloomfield (1933) added that bilingualism is the speakers' skills to use two languages equally proficient. Besides, Bialystok (2006) portrayed bilingual speakers as individuals who utter two languages and act properly in both languages. Lado (1964), however, argued that bilingualism is the ability of speakers regardless of 
the level of proficiency in either one of the languages spoken. These arguments pinpoint nuanced issues to characterize a bilingual speaker by definition.

In Indonesia, Sumarsih et al (2014) reported a great number of bilingual speakers. The bilingual individuals conversed daily with two or more distinct languages and dialects. The study of Sumarsih et al (2014) suggested that Indonesian people have the ability to understand and speak two languages and even more. They highlighted influencing factors that lead to being a bilingual speaker such as mobilization, nationalism, religion, culture, and education.

\section{Code-Switching}

Code-switching is a speech creativity of bilingual speakers. Hoffman (1991) defined codeswitching as the most creative aspect of bilingual speech and added that code-switching is considered a normal phenomenon for bilingual speakers because of its function and they found it easier to communicate certain topics in one dominant language than another. In addition, Grosjean (2010) states that code-switching involves the alternate usage of two linguistic varieties (i.e., dialects within a particular language) or two languages during the conversation among bilinguals.

Code-switching refers to bilinguals' use of two languages in the similar utterances. In other words, being unable to utter a certain word in a target language but say out loud in another language is called code-switching. Such switching in the utterances can be words or phrases in a whole conversation. Code-switching embodies the transition from one language into the other without changing the overall structure of the other languages. Grosjean (2010) asserted that code-switching functions to facilitate communication in which bilingual speakers rarely understand each other. Thus, it can be said that code-switching is the use of two or more languages in the bilingual community's speech. With regard to the current study, code-switching involves alternating the use of code of a particular language to another language code, for instance, code A (Indonesian) shifts to code B (English) and vice versa in conversation and mass media, as in advertisements. Sumarsih et al (2014) identified actual language used in Indonesian society and discovered switching in interactions across local languages to English lexicons. Furthermore, Windyawati and Aurima (2018) explored Indonesian users of Facebook posts and concluded that Indonesian-English switching was likely to use within three major types of code-switching. These studies indicated a salient shifting in Indonesians' language use in their interaction and represented their bilingual identity. 


\section{Types of Code-switching}

Hoffman (1991) categorized code-switching into three major types, based on the scope of switching where one additional language takes place, such as intra-sentential switching, intersentential switching, and emblematic switching or tag switching.

1. Intra-sentential Switching

Intra sentential switching is code-switching that occurs within the sentence boundaries or also a clause. Romaine (2000) said that intra-sentential code-switching occurs at the extent of lexicon, clause, or potentially sentence. In this sense, bilingual or multilingual speakers may potentially switch the part of clauses, lexical items, or morphemes in the conversations.

Romaine (2000) provided an example of intra-sentential code-switching as follows; “This morning I hantar my baby tu dekat babysitter tu lah." (This morning I took my baby to the babysitter). The sample described that the speaker switched between two codes (Malay and English) within a sentence.

\section{Inter-sentential Switching}

Inter-sentential switching involves switching at the sentential extent where one sentence is in one particular language and the subsequent sentence is in the other. This switching is not restricted to the insertion of one or two words. "Itulah. Mama dah gak ada. Adik ni demam ni. Pity you. Your voice also different already. (Stapa \& Khan, 2016)" (That's why. I knew it. Pity you. Your voice sounds different.) The sample described the occurrence of an inter-sentential code switching from Malay to English.

3. Tag Switching

This type of switching is oftentimes called emblematic switching or tag switching. Tag switching is a tag or short phrase inserted from one language into a sentence of another that is entirely otherwise. Tag switching includes sentence tags that precede or follow another sentence. Examples of common English tags are as follows; "you know", "I mean", and "right". JapaneseEnglish tag switching, for example, "I am a nice person, neh? Particle "neh" is inserted to give a teasing tone to the sentence. The same case is also in a Dutch-Indonesian sentence; "Ini baju bagus, toch?" (This is a nice dress, right?). Also, this particular code-switching is common to bilingual speakers when conversing with each other.

\section{Code-switching on TV Advertisements}

Advertisements are a platform that provides a plethora of code-switching samples. Belch and Belch (2003) confirmed that advertising serves a wide variety of objectives such as marketing 
products and services. Televisions, as a commercial medium with advertising at the center of its existence, have profound consequences for language switching. Additionally, TV advertisements are a lucrative way of promoting products, spreading information that potentially affects behavior patterns and linguistic choices of the customers because the ads are broadcasted every day with the intention of influencing the audience.

Gardner and Chloros (2009) mentioned that code-switching puts advertisements as a widely used platform to advocate products and countless examples of English inclusion with local languages in many countries to present exclusivity of the sold products. Furthermore, Auer and Wei (2007) pinpointed that the success of marketing strategies relies on how language choice is considered to play a significant role for the market effectiveness of a particular advertisement. Sintya (2017) explored code-switching uses in Indonesian advertisements and revealed that most product ads involving code-switching were cosmetics, medicines, and hygiene stuff groups. $\mathrm{Da}$ Silva (2014) examined the frequent use of English words in Indonesian ad billboards in Jakarta and raised concerns of English dominant use that serve modernity, youth, and urban lifestyle in Indonesia. These studies have informed the present study to specify the exploration of IndonesianEnglish switching in food commercials as audience targeted range from young to adults for their consumption of the products considering the multilingual context of Indonesia and English is a foreign language taught in high schools only.

\section{Methods}

In accordance with the objectives of the study and the nature of the problem, a qualitative design was used. Descriptive research was employed to observe, find, and describe the information of the phenomenon gathered as many as possible. Therefore, the data were collected, analyzed, and the interpretative conclusion was drawn. Cresswell (2003) stated that qualitative study is fundamentally interpretive. Sugiono (2009) added that descriptive qualitative research is a research method used to investigate the objects in a natural setting and the researcher is a key instrument, collecting the samples, analyzing the data qualitatively and interpret the results which are generally about language and meaning. This implies that the researcher makes an interpretation of the collected data by analyzing the themes or categories to later drawing conclusion about the meaning theoretically and personally.

In carrying out the study, the researcher focused on finding the code-switching (Indonesian Language-English Language) on videos of TV advertisements. Because advertisements included a broad area of themes, therefore the present study specified the scope of advertisements to food 
and beverage products that utilized English-Indonesian code-switching and were more frequently appeared on Indonesian TV channels. The data were taken from spoken and written advertisements from various television stations. However, due to the researcher's limited access to Indonesian television stations, the Food advertisements broadcasted around early 2000 - April 2020 were extracted from YouTube and were publicly available. The ads were gathered from March - April 2020 and classified based on the types of code-switching. Since the specific focus of the study was on food ads, therefore the researcher eliminated some other ads and constrained solely to food commercials available appealing to all ages of viewers on YouTube.

The data collected were analyzed through some stages such as transcribing, identifying, and classifying. In transcribing, the recordings of spoken utterances in the ads were transmitted to written speech. After collecting the data, then categorizing and pairing into the analysis of types of code-switching was an identifying stage. Because the advertisements were randomly selected, they needed to be identified with code-switching utterances contained. Then, continued to further analysis of the finding by putting the utterances into the classification of the types of codeswitching. Classification is the process of classifying the findings based on the categories set. The final stage of the study was analyzing which aimed at distinguishing ads containing code-switching expressions and the types of code-switching and disseminating the findings.

\section{Findings}

The purposes of the study were to identify whether Indonesian TV ads involve codeswitching and to classify the type of code-switching encountered. The data were collected from a number of TV ads played in recent years in Indonesian TV channels and then transcribed by the researcher (see Table 1). Due to the researcher's geographical constraint and access to popular TV channels in Indonesia, so the ads were retrieved from YouTube and used for further analysis of the present study. Of hundreds of TV ads broadcasted regularly in Indonesia, the present study centered on food product advertisements only because of their most frequent appearance and appeal to customers of all ages. Therefore, the following table disseminates the TV ads which involve Indonesian-English code-switching. 
Table 1. Identification of Code-Switching in Indonesian TV Ads

\begin{tabular}{|c|c|c|c|c|}
\hline \multirow{2}{*}{ No } & \multirow{2}{*}{ Advertisements } & \multirow{2}{*}{ Utterances } & \multicolumn{2}{|c|}{ Codeswitching } \\
\hline & & & Yes & No \\
\hline 1 & $\begin{array}{l}\text { Neo Coffee Caramel } \\
\text { Machiato }\end{array}$ & $\begin{array}{l}\text { Are you sure? Gua berani sikat gigi kuda nil } \\
\text { deh! - Bikin like, like, like! }\end{array}$ & $\mathrm{X}$ & \\
\hline 2 & Chitato Maxx & $\begin{array}{l}\text { Jalani hidup to the max bareng chitato max - } \\
\text { Yang lebih wavy, flavorful, dan crunchy to } \\
\text { the max! }\end{array}$ & $\mathrm{X}$ & \\
\hline 3 & Teh Pucuk Harum & $\begin{array}{l}\text { Rasa teh terbaik ada di pucuknya, I want } \\
\text { more! }\end{array}$ & $\mathrm{X}$ & \\
\hline 4 & Mie Sedaap & Mie Sedaap, I like it. Mie Sedaap, we love it. & $\mathrm{X}$ & \\
\hline 5 & KFC Indonesia & $\begin{array}{l}\text { Butuh time-out? Snack-bucket-in aja... } \\
\text { dengan sensasi sweet and spicy... }\end{array}$ & $\mathrm{X}$ & \\
\hline 6 & Richeese Factory & $\begin{array}{l}\text { Cobain lezatnya Fire Chicken! Cheese } \\
\text { sauce-nya berani! Barbeque sauce-nya } \\
\text { berani! }\end{array}$ & $\mathrm{X}$ & \\
\hline 7 & A \& W Restaurants & $\begin{array}{l}\text { Awesome food made by awesome people! } \\
\text { Nikmati lezatnya Mozza Burger dalam paket } \\
\text { kentang hanya di A\&W! }\end{array}$ & $\mathrm{X}$ & \\
\hline 8 & Cheetos Museum & $\begin{array}{l}\text { Harus on-time nih! Teman-teman udah } \\
\text { ready... }\end{array}$ & $\mathrm{X}$ & \\
\hline 9 & Oreo & $\begin{array}{l}\text { Everybody, let's go! Oreo! Open up with } \\
\text { Oreo, tunjukkan ke semua luasnya } \\
\text { imajinasi.... }\end{array}$ & $\mathrm{X}$ & \\
\hline 10 & Aqua & Fully presented in Indonesian & & $\mathrm{X}$ \\
\hline 11 & KITKAT Green Tea & $\begin{array}{l}\text { Break aja dulu, baru siap! Ada break, ada } \\
\text { KITKAT! }\end{array}$ & $\mathrm{X}$ & \\
\hline 12 & $\begin{array}{l}\text { Frisian Flag Full } \\
\text { Cream }\end{array}$ & Fully presented in Indonesian & & $\mathrm{X}$ \\
\hline 13 & Ichi Ocha & $\begin{array}{l}\text { Buka bersama cuma wacana forever, ...malas } \\
\text { nge- } \text { book, ... bikin gerah } \text { body ... }\end{array}$ & $X$ & \\
\hline
\end{tabular}


Journal of Applied Linguistics, Literature and Culture

The table above reported code-switching utterances encountered or were used in Indonesian TV commercials. Of 13 TV ad samples gathered, only 11 ads where EnglishIndonesian code-switching was identified. The code-switching identified food product ads were Neo Coffee Caramel Machiato, Chitato Maxx, Teh Pucuk Harum, Mie Sedaap, KFC, Richeese Factory, A\&WW, Cheetos Museum, Oreo, KitKat, and Ichi Ocha whereas the other two ads; Aqua and Frisian Flag Full Cream used fully Indonesian script.

This subsequent section presented the analysis of the data collected to put the switching into the appropriate categories of the types of code-switching. The utterances of English were highlighted in bold and italics, while regular formats were Indonesian utterances.

Table 2. Classification of Code-Switching in Indonesian TV Ads

\begin{tabular}{|c|c|c|c|c|c|}
\hline \multirow{2}{*}{ No } & \multirow{2}{*}{ Advertisements } & \multirow{2}{*}{ Utterances } & \multicolumn{3}{|c|}{ Type of CS } \\
\hline & & & Tag & Intra & Inter \\
\hline 1 & $\begin{array}{l}\text { Neo Coffee Caramel } \\
\text { Machiato }\end{array}$ & $\begin{array}{l}\text { Are you sure? Gua berani sikat gigi kuda } \\
\text { nil deh! - Bikin like, like, like! }\end{array}$ & & $\mathrm{X}$ & $\mathrm{X}$ \\
\hline 2 & Chitato Maxx & $\begin{array}{l}\text { Jalani hidup to the max bareng chitato max } \\
\text { - Yang lebih wavy, flavorful, dan crunchy } \\
\text { to the max! }\end{array}$ & & $\mathrm{X}$ & \\
\hline 3 & Teh Pucuk Harum & $\begin{array}{l}\text { Rasa teh terbaik ada di pucuknya, I want } \\
\text { more! }\end{array}$ & & & $\mathrm{X}$ \\
\hline 4 & Mie Sedaap & $\begin{array}{l}\text { Mie Sedaap, I like it. Mie Sedaap, we love } \\
\text { it. }\end{array}$ & & & $\mathrm{X}$ \\
\hline 5 & KFC Indonesia & $\begin{array}{l}\text { Butuh time-out? Snack-bucket-in aja... } \\
\text { dengan sensasi } \text { sweet and spicy... }\end{array}$ & & $\mathrm{X}$ & \\
\hline 6 & Richeese Factory & $\begin{array}{l}\text { Cobain lezatnya Fire } \text { Chicken! } \text { Cheese } \\
\text { sauce-nya berani! Barbeque sauce-nya } \\
\text { berani! }\end{array}$ & & $\mathrm{X}$ & \\
\hline 7 & A \& W Restaurants & $\begin{array}{l}\text { Awesome food made by awesome } \\
\text { people! Nikmati lezatnya Mozza Burger } \\
\text { dalam paket kentang hanya di A\&W! }\end{array}$ & & & $\mathrm{X}$ \\
\hline 8 & Cheetos Museum & $\begin{array}{l}\text { Harus on-time nih! Teman-teman udah } \\
\text { ready... }\end{array}$ & & $\mathrm{X}$ & \\
\hline
\end{tabular}




\begin{tabular}{|l|l|l|l|l|c|}
\hline 9 & Oreo & $\begin{array}{l}\text { Everybody, let's go! Oreo! Open up with } \\
\text { Oreo, tunjukkan ke semua luasnya } \\
\text { imajinasi.... }\end{array}$ & & X \\
\hline 10 & Aqua & Fully presented in Indonesian & & & \\
\hline 11 & KITKAT Green Tea & $\begin{array}{l}\text { Break aja dulu, baru siap! Ada break, ada } \\
\text { KITKAT! }\end{array}$ & X & \\
\hline 12 & $\begin{array}{l}\text { Frisian Flag Full } \\
\text { Cream }\end{array}$ & Fully presented in Indonesian & & \\
\hline 13 & $\begin{array}{l}\text { Ichi Ocha } \\
\text { Buka bersama cuma wacana forever, } \\
\ldots \text { malas nge- } \text { book, ... bikin gerah body ... }\end{array}$ & & $\mathrm{X}$ & \\
\hline
\end{tabular}

The data above showed that the majority of the sample code-switching sentences were in intra-sentential switching, seven TV ads. The latter was inter-sentential switching with five TV ads. Unfortunately, of the thirteen samples collected, tag switching was rarely performed regardless of the brands.

Intra-sentential switching is the insertion of words or clauses from one language to another within an utterance. Data in Table 2 demonstrated the inclusion of English words and clauses into Indonesian scripts of the TV ads. Most of the words were nouns describing the specific products of the ads such as fried chicken, barbeque sauce, and many more. Also, adjectives are inserted into such as wavy, crunchy, and verbs modifying the subjects as in sample 1, "bikin like, like, likee!". In Indonesian TV ads, oftentimes subjects were omitted in the sentence, but the audience clearly understands the context.

Moreover, inter-sentential switching involves the use of two languages in subsequent sentences. Data shows that some TV ads used inter-sentential switching, meaning that another language spoken in sentence follows a sentence with another different language. It can be seen, for example, in sample 7, “Awesome food made by awesome people! Nikmati lezatnya Mozza Burger dalam paket kentang hanya di A\&W!". The word "Burger" has been adopted as Indonesian words for pieces of bread filled with beef or sausages. So, in this case, the sample demonstrates intersentential switching.

\section{Discussion and Conclusion}

The objectives of the present study are twofold. First, the study sought to examine codeswitching in Indonesian TV ads particularly in food product commercials. Second, the study classified the types of code-switching encountered in food product commercials in Indonesia. 
Accordingly, by referring to the types of code-switching proposed by Hoffman (1991) and the data gathered in the present study, the findings provided interesting facts with regard to codeswitching. The findings indicated that code-switching was likely to occur in Indonesian TV ads. This is due to the majority of samples investigated use English words and phrases along with Indonesian sentences. The most frequently encountered type of code-switching in this particular study was intra-sentential switching. Unfortunately, tag switching in this study was rare to identify. The findings resonate with the results of Windyawati and Aurima's (2018) study on code-mixed Facebook posts of Indonesian users.

The results of the present study support previous studies conducted by Da Silva (2014) and Sintya (2017). It should be acknowledged that such code-switching encompasses a result of the current status of English as a global language and a language of prestige for marketing (Martin, 2006). Additionally, English use is acceptable worldwide so as a result, it gains a privilege over other languages spoken worldwide (Martin, 2006). Da Silva (2014) pointed out that the usage of the English language in product ads creates a positive image towards the brands. This simply implies that internationally recognized products use English to leverage their price in both international and domestic markets. However, there seems to have a balanced use of Indonesian language in the product ads. The findings denoted a fair amount of Indonesian expressions along with English utterances. This is obvious to say that the product agents consider the target costumers when advertising their goods. It is crucial to note that both languages, Indonesian and English, have their audience and bridge communication barriers.

To sum up, this study has provided further evidence of code-switching in Indonesian TV ads, particularly food products. Also, the classification of the types of code-switching in those ads has been examined in the study. However, there is a critical need to explore what people perceive about such Indonesian-English switches. The results raise questions on comprehensive factors and appropriate language choice to sell products for multilingual society in Indonesia. This is to say that future study seeks for understanding the underpinning factors for code-switching of advertised food products targeting a particular society. Moreover, it is important to examine if the transfer of language complies with the rule or structure of either the mother tongue (L1) or the second language (L2). From an educational perspective, it would be fascinating to explore the impact of frequent exposure to Indonesian-English code-switching towards EFL learners' vocabulary acquisition and retainment. 


\section{Disclosure statement}

The author of this article declares that he has no conflict of interest.

\section{Acknowledgments}

The author would like to express his sincere gratitude to Dr. Usha Lakshmanan for her valuable comments, patient guidance, and constructive feedback during the process of collecting data, analyzing, and writing the report of the research. The author would also like to sincerely appreciate anonymous reviewers of Huele Journal for insightful and thorough feedback, comments, and critics for revisions of the paper in any aspects until it is completed and has helped to publish this work.

\section{References}

Attariba, J., \& Morier, R. G. (2006). Bilingualism: Language, Emotion, and Mental Health. In T. K. Bhatia, \& W. C. Ritchie (Eds), The Handbook of Bilingualism (pp. 250-281). Oxford: Blackwell.

Auer, P. and Wei, L. (2007). Handbooks of Multilingualism and Multilingual in Communication. Berlin: Walter de Gruyter GmbH \& Co.

Belch, G. E., \& Belch, M. A. (2003). Advertising and Promotion: An Integrated Marketing Communications Perspective. New York: McGraw Hill.

Bialystok, E. (2006). Bilingualism in Development: Language, Literacy, \& Cognition. UK: Cambridge University Press.

Bloomfield, L. (1933). Language. New York: Holt, Rinehart, and Winston.

Creswell, J. W. (2003). Research Design: Qualitative, Quantitative and Mixed Methods Approaches. London: Sage Publications.

Da Silva, A. M. (2014). Upon the Prevalence of English on Billboard Advertisements: Analyzing the Role of English in Indonesian Contexts. TEFLIN Journal, 25 (1), 33-61.

Edwards, J. (2006). Foundations of Bilingualism. In T. K. Bhatia, \& W. C. Ritchie (Eds.), The Handbook of Bilingualism (pp. 7-31). Oxford: Blackwell.

Gardner-Chloros, P. (2009). Code-Switching. New York: Cambridge University Press.

Grosjean, F. (2010). Bilingual: Life and reality. Cambridge: Harvard University Press.

Hoffman, Charlotte. (1991). An Introduction to Bilingualism. New York: Longman.

Martin, E. (2006). Marketing Identities through Language: English and Global Imagery in French Advertising.

New York: Palgrave Macmillan. 
Romaine, S. (2000). Language in society: An introduction to sociolinguistics. Oxford: Oxford University Press.

Sintya, M. W. E. (2017). Code-Switching and Code-Mixing on Persuasion in Indonesian Television Advertisements. Proceedings: International Seminar on Language Maintenance and Shift. p. 630-636.

Stapa, N. \& Khan, N. (2016). Functions of code-switching: A case study of a mixed Malay- Chinese family in the home domain, Pertanika J. Soc. Sci. \& Hum. 24(S), 181-194.

Sugiono. (2009). Metode Penelitian Pendidikan. Bandung: Alfabeta.

Sumarsih, S., Masitowarni, S., Bahri, S., \& Sanjaya, D. (2014). Code Switching and Code Mixing in Indonesia: Study in Sociolinguistics? English Language and Literature Studies, 4(1), 77. https://doi.org/10.5539/ells/v4n1p77

Titone, R. (1993). Bilinguismo Precoce ed Educazione Bilingue. Armando Editore: Roma.

Windyawati, \& Aurima, Y. O. (2018). An Analysis of Indonesia English Code-Mixing in Facebook Status Users. Project: Professional Journal of English Education, 5(1), 539-544. 